\title{
SCHWA IN ABKHAZ
}

\author{
Tamio Yanagisawa \\ (Nagoya University)
}

(Key words: Abkhaz, schwa, North West Caucasian)

\section{Introduction *}

Abkhaz is one of the languages in the North West Caucasian family. North West Caucasian languages are well known for their large consonantal and small vocalic inventories. Many investigators of Abkhaz (e.g. Lomtatidze, Hewitt, Chirikba) regard the linear two member /a - ə / as its vocalic system. However, there has been discussion as to whether or not this schwa $ə$ can be regarded as a phoneme. For instance, Allen (1965) suggested that Abaza, which has a dialectal relationship to Abkhaz, is monovocalic, and has only the single vowel /a/. Kuipers (1960) has also claimed an absence of consonant-vowel opposition in the phonemic system of Kabardian, another member of the North West Caucasian linguistic family. According to Kuipers' analysis of Kabardian, the presence or absence of its postaccentual schwa can be predicted according to certain rules that he has established. On the other hand, the preaccentual schwa can be eliminated from the system of phonemes in keeping with Kuipers' interpretation of the opposition a versus zero as a "juncture-phenomenon".

To date, the occurrences of unstressed schwa in Abkhaz have not been investigated in detail in Caucasology. In this article I will undertake such an investigation, and argue that the presence or absence of an unstressed schwa in Abkhaz is predictable. I will look at the circumstances under which unstressed schwa appear, dividing them into postaccentual and preaccentual occurrences.

I have classifed all consonants in the following three series, from the point of view of sonority: 
Series I :

stops: labials. $b-p-p^{\prime}$, dentals. $d-t-t^{\prime}, d^{w}-t^{w}-t^{\prime}{ }^{w}$, velars. $g-k-k^{\prime}, g^{w}-k^{w}-k^{\prime}{ }^{w}$, $g^{j}-k^{j}-k^{\prime} j$, uvulars. $q^{\prime}, q^{\prime}{ }^{w}, q^{\prime}$

affricates: dentals. $3-c-c^{\prime}, 3^{w}-c^{w}-c^{\prime} w$, alveolars. $\breve{3}-\check{c}^{-} \check{c}^{\prime}, \check{3}^{j}-\check{c}^{j}-\check{c}^{\prime} j$

fricatives: dentolabials. $v$-f, dentals. $z-s$, alveolars. $\check{z}-\check{s}, \check{Z}^{w}-\check{s}^{w}, \check{Z}^{j} \check{S}_{-}$, uvulars. $\gamma-X, \gamma^{w}-X^{w}, \gamma^{j}-X^{j}$, pharyngals. $h, h^{w}, j^{w 1}$

Series II : resonants: $n, m, r, l$

Series III : semivowels: $j, w$

$<^{\prime}>$ = glottalization, $\left.<^{\mathrm{w}}\right\rangle=$ labialization, $\left.<^{\mathrm{j}}\right\rangle=$ palatalization

The words and verbal forms cited below as examples are from data collected from Mrs. Ana Tsvinaria, a native speaker of the Abzhywa dialect of Abkhaz, who acted as a consultant during the course of fieldwork.

\section{The postaccentual occurrence of schwa}

Before discussing the occurrence of schwa, I should clarify the relation between schwa and stress in Abkhaz. To describe the placement of stress in Abkhaz words, Spruit (1985:31) postulates that each word should be considered as "consisting of a string of elements $C(\partial)$ or $C a$ (where $C$ is any consonant)" which is subsumed under the generic symbol " $C(a)$ ". According to Spruit, "a stressed element $C(a)$ is realized as $C a ́$ or, in the absence of a, as Cá" (e.g. á-3 "theflea", á-3-kwa "the-flea-pl." versus a-zó "the-water", a-3-kwá "the-water-pl."). Therefore, a schwa bearing stress can be viewed as a realization of stress on the preceding consonant. I will call this consonant a potentially stressed consonant. $^{2}$ Moreover, the schwa disappears before $a$ (e.g. $d ə-s-k$ '-wá-jt' "I catch him/her" versus $d$-a-k'-wá-jt' "it catches him/her").

If all consonants are marked as $C$, vowels $a$ and $ə$ as $V$, derivational boundaries as \#, and word-boundaries as \#\#, the presence or absence of a postaccentual schwa is conditioned in such consonant sequences as per the following:

1) - $\mathrm{VC}_{1} \curvearrowright \mathrm{C}_{2} \# \#$, 2) - $\mathrm{aC}_{1} \mathrm{C}_{2} \# \#$, 3) $\left.-\mathrm{VC}_{1} \mathrm{C}_{2} \ni \mathrm{C}_{3} \# \#, 4\right)-\mathrm{VC}_{1} \ni \mathrm{C}_{2} \mathrm{C}_{3} \# \#$, 5) $\left.\left.\left.-\mathrm{VC}_{1} \curvearrowright \mathrm{C}_{2} \mathrm{C}_{3} \mathrm{~V}(\# \# /-), 6\right)-\mathrm{VC}_{1} \mathrm{C}_{2} \ni \mathrm{C}_{3} \mathrm{~V}-, \mathrm{7}\right)-\mathrm{VC}_{1} \partial \mathrm{C}_{2} \mathrm{C}_{3} \mathrm{C}_{4} \mathrm{~V}-, 8\right)-\mathrm{VC}_{1} \mathrm{C}_{2} \partial \mathrm{C}_{3} \mathrm{C}_{4} \mathrm{~V}-$, 9) -Cə\#\#.

We can now look, in greater detail, at each of these consonant sequences. 


\section{$2.1-\mathrm{VC}_{1} \curvearrowright \mathrm{C}_{2} \#$}

Examples where a schwa appears between $\mathrm{C}_{1}$ and $\mathrm{C}_{2}$ are as follows:

a) $\mathrm{C}_{1}=$ Series I, $\mathrm{C}_{2}=$ Series I: áaxəs "from", áx ${ }^{j}(\partial) 3$ "name", álax"əc "eyelash",

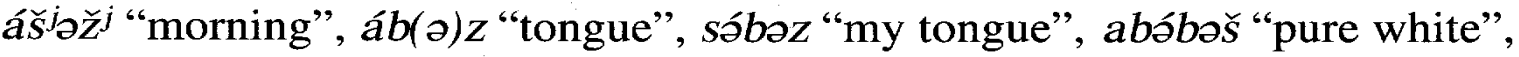
ác"(ə)X "night", jəlmósəz "one who hit her and", ádəd "thunder".

b) $\mathrm{C}_{1}=$ Series I, $\mathrm{C}_{2}=$ Series II: áapon "spring", ájatəm "orphan", ázən "winter", dók ${ }^{w} ә m$ "he/she is not on", jók wəon "it was on", bəsmósən "don't hit me!".

In general, sonority is thought to become higher to the right according to the following hierarchy: "voiceless stops < voiceless fricatives < voiced stops < voiced fricatives < resonants < semivowels." In the case of a) above, when $C_{1}$ is a voiced stop and $\mathrm{C}_{2}$ is a voiced fricative (e.g. sábəz, áb(ə)z, with the exception of the word $a b$ óbəš), or when $C_{1}$ is a voiceless fricative and $C_{2}$ is a voiced

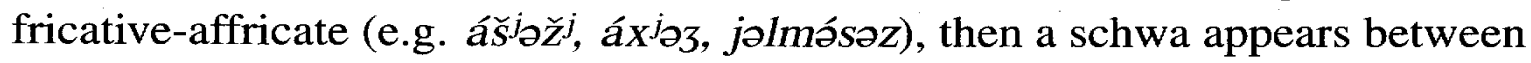
$\mathrm{C}_{1}$ and $\mathrm{C}_{2}$. Also, when both $\mathrm{C}_{1}$ and $\mathrm{C}_{2}$ are voiceless fricative-affricates (e.g. áaxəs, ác'əx), or when both $\mathrm{C}_{1}$ and $\mathrm{C}_{2}$ are voiced stops (e.g. ádəd), then a schwa appears between $C_{1}$ and $C_{2}$. In the case of $b$ ) above, where the sonority of $\mathrm{C}_{1}$ is lower than that of $\mathrm{C}_{2}$, a schwa appears between $\mathrm{C}_{1}$ and $\mathrm{C}_{2}$.

\section{$2.2-\mathrm{VC}_{1} \mathrm{C}_{2} \# \#$}

Examples where a schwa does not appear between $\mathrm{C}_{1}$ and $\mathrm{C}_{2}$ are as follows:

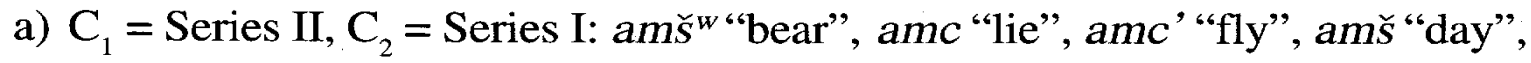
ans "so", ant "those", anóh wam̌s "holiday", akórc "dandruff", amč "force", axólc' "descendant".

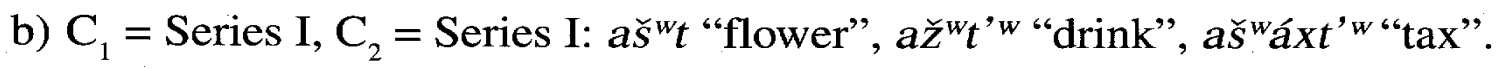

In a), where the sonority of $C_{1}$ is higher than that of $C_{2}$, a schwa does not appear between $C_{1}$ and $C_{2}$. In $b$ ), when $C_{1}$ is a voiceless fricative and $C_{2}$ is a voiceless stop, and thus the sonority of $\mathrm{C}_{1}$ is higher than that of $\mathrm{C}_{2}$, a schwa does not appear between $\mathrm{C}_{1}$ and $\mathrm{C}_{2}$ (with the exception of the word sbósop" "I'll hit you"3).

Comparing the examples in 2.1 above with those given here, it can be seen that if the sonority of $C_{1}$ is lower than that of $C_{2}$, or the sonority of $C_{1}$ is the same as that of $\mathrm{C}_{2}$, then a schwa tends to appear between $\mathrm{C}_{1}$ and $\mathrm{C}_{2}$. On the other hand, if the sonority of $\mathrm{C}_{1}$ is higher than that of $\mathrm{C}_{2}$, then a schwa does not appear between $\mathrm{C}_{1}$ and $\mathrm{C}_{2}$. However, when both $\mathrm{C}_{1}$ and $\mathrm{C}_{2}$ belong to Series $\mathrm{I}$, there are instances where this rule does not apply. 


\section{$2.3-\mathrm{VC}_{1} \mathrm{C}_{2} \curvearrowright \mathrm{C}_{3} \#$}

Examples where a schwa appears between $\mathrm{C}_{2}$ and $\mathrm{C}_{3}$ are as follows:

a) $\mathrm{C}_{1}=$ Series $\mathrm{I}, \mathrm{C}_{2}=$ Series I, $\mathrm{C}_{3}=$ Series II: áč’k'wən "boy", ádgjəl "earth", apsádgjol "homeland".

b) $\mathrm{C}_{1}=$ Series II, $\mathrm{C}_{2}=$ Series I, $\mathrm{C}_{3}=$ Series II: ámp'al "ball", ák' "əmp'əl "round".

c) $\mathrm{C}_{1}=$ Series $\mathrm{I}, \mathrm{C}_{2}=$ Series $\mathrm{I}, \mathrm{C}_{3}=$ Series I: ás̆ ${ }^{w}$ təc "single flower", álabžə̌̆ “tear”, áškwos (Genko:1998) "year”.

d) $\mathrm{C}_{1}=$ Series II, $\mathrm{C}_{2}=$ Series I, $\mathrm{C}_{3}=$ Series I: ántəc' "outside", árpəs "youth".

e) $\mathrm{C}_{1}=$ Series I, $\mathrm{C}_{2}=$ Series II, $\mathrm{C}_{3}=$ Series II: sbósrəm "I will not hit you".

In a), b), c) and $d$ ), the sonority of $C_{1}$ is the same as that of $C_{2}$ (cf. ádgjol), or the sonority of $\mathrm{C}_{1}$ is higher than that of $\mathrm{C}_{2}$ (cf. áč' $k^{\prime}{ }^{\prime}$ ən, ámp'əl, ántəc'), while the sonority of $\mathrm{C}_{2}$ is lower than that of $\mathrm{C}_{3}$, with the exception of the word álabžəs. This relation of sonorities in the consonant sequences shows that a syllable break exists between $\mathrm{C}_{1}$ and $\mathrm{C}_{2}$, and therefore the preceding vowel and $\mathrm{C}_{1}$ form a syllable, while between $\mathrm{C}_{2}$ and $\mathrm{C}_{3}$ a schwa occurs as a syllabic peak. In the case of e), where the sonority of $\mathrm{C}_{2}$ is the same as that of $\mathrm{C}_{3}$ (as opposed to the examples in 2.4 below), a syllable break exists between $C_{1}$ and $C_{2}$ and a schwa can appear as a syllabic peak between $\mathrm{C}_{2}$ and $\mathrm{C}_{3}$. If the consonants in Series $\mathrm{I}$ are identified with a $T$, and the resonants and semivowels in Series II and III with an $R$, then the examples above can be represented as follows: a) VTTəR\#\#, b) -VRTəR\#\#, c) VTTəT\#\#, d) VRTəT\#\#, e) -VTRəR\#\#.

\section{$2.4-\mathrm{VC}_{1} \ni \mathrm{C}_{2} \mathrm{C}_{3} \#$}

Examples where a schwa appears between $\mathrm{C}_{1}$ and $\mathrm{C}_{2}$ are as follows:

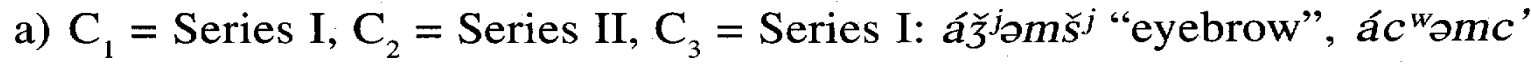
"gadfly", álayorz "tear".

b) $\mathrm{C}_{1}=$ Series I, $\mathrm{C}_{2}=$ Series III, $\mathrm{C}_{3}=$ Series I: dlósəjt' "he/she hit her", jók wəwp' "it /they is/are on".

As stated above (cf. 2.2 amš ${ }^{w}$ ), a schwa does not appear between $\mathrm{C}_{2}$ and $\mathrm{C}_{3}$ because the sonority of $\mathrm{C}_{2}$ is higher than that of $\mathrm{C}_{3}$, while a schwa appears between $C_{1}$ and $C_{2}$ because the sonority of $C_{1}$ is lower than that of $C_{2}$ (cf. 2.1 ázon). From the examples given here it can be seen that in a three-consonant sequence like -VTRT\#\#, a schwa can appear before $R$ followed by $T$ : $-V T \partial R T \# \#$. These examples, including those in 2.1, 2.2 and 2.3 above, generally indicate

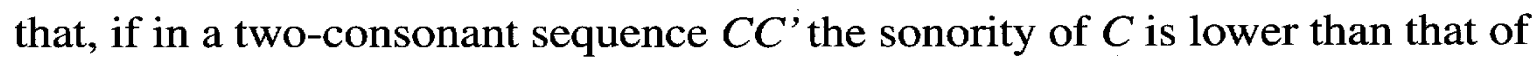


$C^{\prime}$, or the sonority of $C$ is the same as that of $C^{\prime}$, then a schwa can appear between $C$ and $C^{\prime}$. In contrast, if the sonority of $C$ is higher than that of $C^{\prime}$, then a schwa cannot appear between $C$ and $C^{\prime}$. I will call this determination of the appearance of schwa in keeping with sonority the principle of sonority. According to this principle, in a three-consonant sequence like $-V C C^{\prime} C^{\prime}$ "\#\#, a schwa can appear either between $C$ and $C^{\prime}$ or between $C^{\prime}$ and $C^{\prime \prime}$.

Examples of three-consonant sequences in which a schwa appears before $\mathrm{C}_{2}$ of Series I (e.g. -VTəTT\#) are not found in my data, but examples of four-consonant sequences wherein consonants of Series $I$ are present are as follows:

c) $\mathrm{C}_{1}=$ Series I, $\mathrm{C}_{2}=$ Series I, $\mathrm{C}_{3}=$ Series I, $\mathrm{C}_{4}=$ Series I: ášitobžj "sound".

d) $\mathrm{C}_{1}=$ Series II, $\mathrm{C}_{2}=$ Series I, $\mathrm{C}_{3}=$ Series I, $\mathrm{C}_{4}=$ Series I: ámčəbž $\check{z}^{j}$ "week". According to the principle of sonority noted above, it is possible that a schwa appears either between $\mathrm{C}_{2}$ and $\mathrm{C}_{3}$ or between $\mathrm{C}_{3}$ and $\mathrm{C}_{4}$. However, these examples would appear to show that a schwa can appear more readily between a voiceless stop/fricative and a voiced stop than between a voiced stop and a voiced fricative.

\section{$2.5-\mathrm{VC}_{1}{ } \mathrm{CC}_{2} \mathrm{C}_{3} \mathrm{V \# \# /-}$}

Examples where a schwa appears between $\mathrm{C}_{1}$ and $\mathrm{C}_{2}$ in a three-consonant sequence followed by a vowel are as follows:

a) $\mathrm{C}_{1}=$ Series I, $\mathrm{C}_{2}=$ Series II, $\mathrm{C}_{3}=$ Series II: áapənra "spring", ázənra "winter season".

b) $\mathrm{C}_{1}=$ Series I, $\mathrm{C}_{2}=$ Series II, $\mathrm{C}_{3}=$ Series I: áfərh"a "quickly", ázaxərta "sewing place", ás̆"ərj" a "smoked cheese", dtózəmgajt' "I did not take him/her out".

c) $\mathrm{C}_{1}=$ Series I, $\mathrm{C}_{2}=$ Series I, $\mathrm{C}_{3}=$ Series II: álak'əosra "to touch".

d) $\mathrm{C}_{1}=$ Series II, $\mathrm{C}_{2}=$ Series I, $\mathrm{C}_{3}=$ Series I: aáməร̌ $\operatorname{tax}^{j}$ "after”, álaməsda "conscienceless".

e) $\mathrm{C}_{1}=$ Series II, $\mathrm{C}_{2}=$ Series II, $\mathrm{C}_{3}=$ Series I: jólomtəj "(that) which she did not sell", lč́llomš̀jojt' "she did not kill herself".

f) $\mathrm{C}_{1}=$ Series I, $\mathrm{C}_{2}=$ Series I, $\mathrm{C}_{3}=$ Series I: áhwozba "knife".

In his distinguished monograph on phoneme and morpheme in Kabardian, Kuipers (1960:41) states that "ə never appears before a consonant followed by a except that after plosives, fricatives and glottalic laryngals it appears facultatively before -ra". This rule is also applicable, by extension, to Abkhaz, where a schwa does not appear before a consonant followed by both $a$ and $ə$. 
According to Kuipers' explanation (1960:42), this is because "a consonant followed by a constitutes the rising part of a syllable, and therefore does not itself give rise to another syllabic peak, cf. fzóm versus $k$ 'wážma”. I will call this revised rule for Abkhaz Kuipers' Rule.

In keeping with Kuipers' Rule, a schwa does not appear between $\mathrm{C}_{2}$ and $\mathrm{C}_{3}$ in any of the examples above. In the case of a), b), c) and f), a schwa appears between $\mathrm{C}_{1}$ and $\mathrm{C}_{2}$, since the sonority of $\mathrm{C}_{1}$ is lower than that of $\mathrm{C}_{2}$, that is, the principle of sonority may be applied here (cf. 1.1. ázon). Examples in d) constitute an exception to the principle of sonority (cf. ámc). Presumably, these examples can be explained by "the rule of three-consonant sequences": "in threeconsonant sequences o, if it appears, will be found between the first and second consonant" (Spruit:1985:77). Though this rule does not always operate in threeconsonant sequences (cf. 2.3), it almost always holds true for three-consonant sequences if a schwa cannot appear between $\mathrm{C}_{2}$ and $\mathrm{C}_{3}$. I will call this revised rule Spruit's Rule. Examples in e) can also be explained by Spruit's Rule.

These examples can be represented as follows: a) $V T \partial R R V$, b) $V T \partial R T V$, c) $V T \partial T R V$, d) $V R \partial T T V$, e) $V R \partial R T V$, f) $V T \partial T T V$.

\section{$2.6-\mathrm{VC}_{1} \mathrm{C}_{2} \textrm{C}_{3} \mathrm{~V}-$}

Examples where a schwa appears between $\mathrm{C}_{2}$ and $\mathrm{C}_{3}$ in a three-consonant sequence followed by a vowel are as follows:

a) $\mathrm{C}_{1}=$ Series II, $\mathrm{C}_{2}=$ Series I, $\mathrm{C}_{3}=$ Series I: jómj ${ }^{\text {wəs̆a }}$ "(the one) who may not run".

b) $\mathrm{C}_{1}=$ Series II, $\mathrm{C}_{2}=$ Series I, $\mathrm{C}_{3}=$ Series II: árd"ona "thrush".

These examples appear to be exceptions to both Kuipers' Rule and Spruit's Rule. However, Example a) can be explained by Trigo's Rule (for details of this rule, see 3.3). According to Trigo's Rule, if a form is a verbal complex, a derivational boundary can be considered to exist after its root. In this case the form can be analyzed as jámj $j^{\mathrm{w} \#-s ̌ a, ~ a n d ~ t h e r e f o r e ~ a ~ s c h w a ~ d o e s ~ n o t ~ a p p e a r ~ b e t w e e n ~} m$ and $j^{w}$ (for $ə$ after $j^{w}$ see 2.9). On the other hand, Example b) can be formulated as $V R T \partial R V$. A construction along the lines of $V R T \partial R V$ is not to be found among the examples in 2.5 above. Presumably, in a construction such as $-V R C_{2} C_{3} V$-, the principle of sonority which operates between $\mathrm{C}_{2}$ of Series I and $\mathrm{C}_{3}$ of Series II (or III) may take precedence over Kuipers' Rule. 


\section{$2.7-\mathrm{VC}_{1} ə \mathrm{C}_{2} \mathrm{C}_{3} \mathrm{C}_{4} \mathrm{~V}$ -}

Examples where a schwa appears between $\mathrm{C}_{1}$ and $\mathrm{C}_{2}$ in a four-consonant sequence followed by a vowel are as follows:

a) $\mathrm{C}_{1}=$ Series I, $\mathrm{C}_{2}=$ Series II, $\mathrm{C}_{3}=$ Series I, $\mathrm{C}_{4}=$ Series I: ázaxərsta "seam".

b) $\mathrm{C}_{1}=$ Series I, $\mathrm{C}_{2}=$ Series II, $\mathrm{C}_{3}=$ Series I, $\mathrm{C}_{4}=$ Series II: ázərj" ${ }^{\mathrm{w} a}$ "to listen".

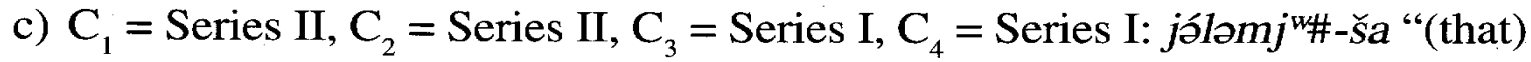
which she may not write".

d) $\mathrm{C}_{1}=$ Series I, $\mathrm{C}_{2}=$ Series II, $\mathrm{C}_{3}=$ Series I, $\mathrm{C}_{4}=$ Series III: jtózomš\#-waz "(the one) who was not immersing it/them".

e) $\mathrm{C}_{1}=$ Series II, $\mathrm{C}_{2}=$ Series II, $\mathrm{C}_{3}=$ Series I, $\mathrm{C}_{4}=$ Series III: jólomx\#-wa "(that) which she does not sharpen".

These examples have no schwa before $\mathrm{C}_{4}$, in keeping with Kuipers' Rule. In a) and $b$ ), the principle of sonority works among the first three consonants $\left(\mathrm{C}_{1} \mathrm{C}_{2} \mathrm{C}_{3}\right)$, and since the sonority of $\mathrm{C}_{1}$ is lower than that of $\mathrm{C}_{2}$ and the sonority of $\mathrm{C}_{2}$ is higher than that of $\mathrm{C}_{3}$, a schwa appears between $\mathrm{C}_{1}$ and $\mathrm{C}_{2}$. These examples can be represented as follows: a) -VTəRTTV\#\#, b) -VTəRTRV\#\#. In the case of c), d) and e), a derivational boundary can be considered to exist after their roots in accordance with Trigo's Rule, and we can assume that the principle of sonority, or Spruit's Rule, operate only among the first three consonants $\left(\mathrm{C}_{1} \mathrm{C}_{2} \mathrm{C}_{3}\right)$. These examples can be represented as follows: c) -VRəRT\#TV-, d)

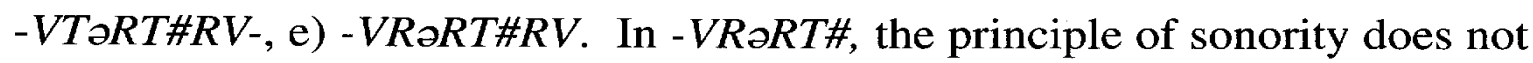
allow a schwa to appear between $R$ and $T$, while a schwa can appear between $\mathrm{C}_{1}$ and $\mathrm{C}_{2}$ following Spruit's Rule.

\section{$2.8-\mathrm{VC}_{1} \mathrm{C}_{2} ə \mathrm{C}_{3} \mathrm{C}_{4} \mathrm{~V}-$}

Examples where a schwa appears between $\mathrm{C}_{2}$ and $\mathrm{C}_{3}$ in a four-consonant sequence followed by a vowel are as follows:

a) $\mathrm{C}_{1}=$ Series II, $\mathrm{C}_{2}=$ Series I, $\mathrm{C}_{3}=$ Series I, $\mathrm{C}_{4}=$ Series I: árpozba "young man". This example has schwa between $\mathrm{C}_{2}$ and $\mathrm{C}_{3}$ because both Kuipers' Rule and the principle of sonority apply (cf. $2.3 \mathrm{~d}$ ) and 2.6).

\section{9 -Co\#\#}

An unstressed schwa also appears word-finally as in the following:

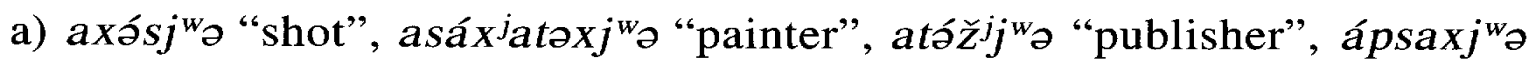

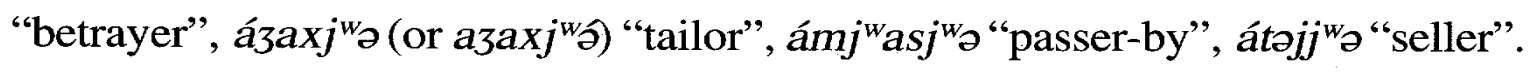




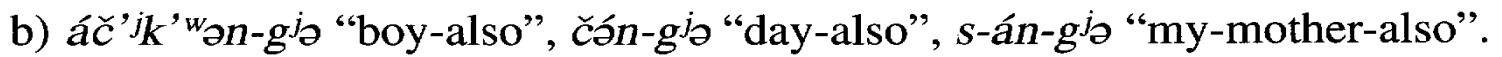

c) ast'ól-č’ə “desk-in”, ámjw-č’ə "road-in”, awáda-č’ə “room-in”, ábna-č’ə "forest-in".

d) dópanə "he/she having jumped", sbác"hanə "I having scolded you".

In the case of a), a schwa appears after the suffix $j^{w}$ which marks deverbal nomina agentis. If there is an a before this suffix, the schwa tends to be dropped:

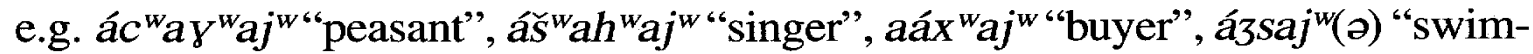

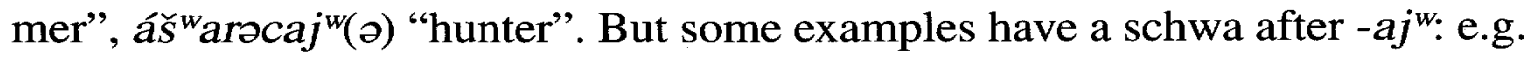
áč́́waj"ə "horseman", árwajwə "soldier". In the case of b), the suffix meaning "also", "even", and "and" has a word-final schwa. However, in some folktale texts this suffix is also found without schwa, e.g. awaá-gi "people-also", apára$g^{j}$ "money-also". In the case of c), the postpositional suffix č’ meaning "in" normally has a schwa, but it tends to be dropped if there is an a before č’ $ə$, e.g. $h$ - $h$ wəntkárra-č " "our-state-in", abáhčja-č '(ə) "garden-in", akóta-č’(ə) "villagein". In the case of e), the word-final suffix no marks the positive form of absolutive and contrasts with the suffix of the past indefinite without a schwa: cf. dópan "he/she jumped and...", sbác"wan "I scolded you and...". The schwa of no is characterized morphologically and not phonetically.

\section{The preaccentual occurrence of schwa}

The presence or absence of the preaccentual schwa is conditioned in consonant sequences such as the following: 1) $-\mathrm{C}_{1} \curvearrowright \mathrm{C}_{2} \mathrm{C}_{3} \mathrm{~V}-$, , 2) $-\mathrm{C}_{1} \curvearrowright \mathrm{C}_{2} \mathrm{C}_{3} \mathrm{C}_{4} \mathrm{~V}-, 3$ ) $\mathrm{C}_{1} \curvearrowright \mathrm{C}_{2} \mathrm{C}_{3} \#-\mathrm{C}_{4} \mathrm{~V}$ - or $\left.-\mathrm{VC}_{1} \curvearrowright \mathrm{C}_{2} \mathrm{C}_{3} \#-\mathrm{C}_{4} \mathrm{~V}-, 4\right)-\mathrm{C}_{1} \mathrm{C}_{2} \curvearrowright \mathrm{C}_{3} \mathrm{C}_{4} \mathrm{V \# -}$.

\section{$3.1-\mathrm{C}_{1} \curvearrowright \mathrm{C}_{2} \mathrm{C}_{3} \mathrm{~V}$ -}

Examples where a schwa appears between $\mathrm{C}_{1}$ and $\mathrm{C}_{2}$ in a three-consonant sequence followed by a vowel are as follows:

a) $\mathrm{C}_{1}=$ Series I, $\mathrm{C}_{2}=$ Series II, $\mathrm{C}_{3}=$ Series I: aq'ərq'əə "throat", axərc'wる "lactic

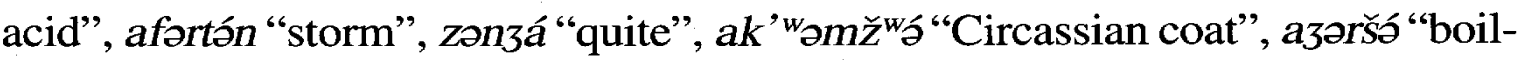

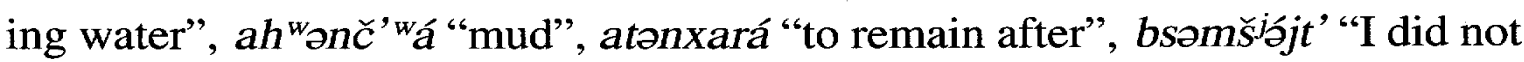
kill you", doľ̌jájt " "she deceived him/her", dolk' wabájt' "she washed him/her". b) $\mathrm{C}_{1}=$ Series I, $\mathrm{C}_{2}=$ Series II, $\mathrm{C}_{3}=$ Series II: ak'ormót' "brick", abəlrá "to burn", ažjornóh"a "January".

c) $\mathrm{C}_{1}=$ Series $\mathrm{I}, \mathrm{C}_{2}=$ Series I, $\mathrm{C}_{3}=$ Series I: axədc'á “duty”, c wəbbón 
"September", acwək' wbár"drop", ax"ətx"ə̌tra "to whisper", ac"əpxašjára "to be ashamed of", səšwžjá "deceive me!", bozbájt' "I saw you", bozgájt' "I took you", dəsq'ažájt' "I calmed him/her”, bəzdórəjt' "I knew you”, bəzdórwajt' "I know you".

d) $\mathrm{C}_{1} 1=$ Series I, $\mathrm{C}_{2}=$ Series I, $\mathrm{C}_{3}=$ Series II: afəj ${ }^{w} r a ́$ "to smell at".

None of these examples have schwa before $\mathrm{C}_{3}$ and this is consistent with Kuipers' Rule. In a) and b), a schwa appears between $C_{1}$ and $C_{2}$ in keeping with both the principle of sonority and Spruit's Rule. In the examples listed in c) and d), since their constructions are $-T T T V$ - and $-T T R V$ - respectively, the principle of sonority which operates between $\mathrm{C}_{2}$ and $\mathrm{C}_{3}$ does not take precedence over Kuipers' Rule (cf. - $R T R V$ - in 2.6). Therefore, in keeping with Kuipers' Rule, a schwa does not appear before $\mathrm{C}_{3}$. The appearance of a schwa in these examples can be explained in terms of either the principle of sonority (cf. axədc'á) or

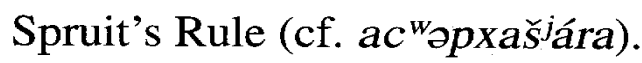

\section{2 $-\mathrm{C}_{1} \partial \mathrm{C}_{2} \mathrm{C}_{3} \mathrm{C}_{4} \mathrm{~V}-$}

Examples where a schwa appears between $\mathrm{C}_{1}$ and $\mathrm{C}_{2}$ in a four-consonant sequence followed by a vowel are as follows:

a) $\mathrm{C}_{1}=$ Series I, $\mathrm{C}_{2}=$ Series II, $\mathrm{C}_{3}=$ Series I, $\mathrm{C}_{4}=$ Series I: ah"ontkár "king",

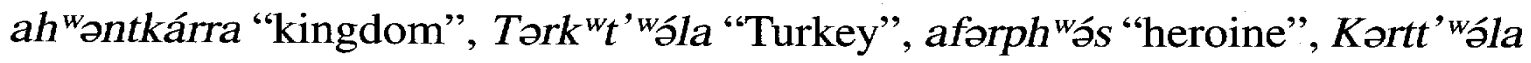
"Georgia”, bəmpš́n "don't look!" (note that a schwa cannot be inserted into a

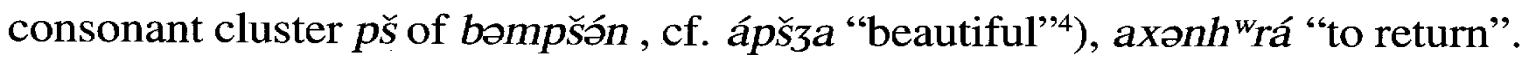
b) $\mathrm{C}_{1}=$ Series I, $\mathrm{C}_{2}=$ Series I, $\mathrm{C}_{3}=$ Series I, $\mathrm{C}_{4}=$ Series II: dəbsmordárəjt' "I did not introduce him/her to you".

In a) and b), since their constructions are -TəRTTV-and -TəTTRV-, the principle of sonority which operates between $\mathrm{C}_{3}$ and $\mathrm{C}_{4}$ does not take precedence over Kuipers' Rule (cf. -RTRV- in 2.6 and $-T T R V$ - in 3.1). Therefore, in keeping with Kuipers' Rule, these examples also have no schwa before $\mathrm{C}_{4}$. With the first three-consonant sequences, the appearance of a schwa between $C_{1}$ and $C_{2}$ is in accord with the principle of sonority.

\section{$3.3 \mathrm{C}_{1} ə \mathrm{C}_{2} \mathrm{C}_{3} \#-\mathrm{C}_{4} \mathrm{~V}$ - or $-\mathrm{VC}_{1} ə \mathrm{C}_{2} \mathrm{C}_{3} \#-\mathrm{C}_{4} \mathrm{~V}$ -}

In Trigo's view (1992:200-201), a verbal complex such as jtasərc ${ }^{w} w a ́ j t$ ' "I make it empty" has a derivational boundary after a root $c^{w}$, i.e. jtasorc ${ }^{w \#-w a ́ j t ' . ~}$ This means then that the presence of $\mathrm{C}_{4}$ after a root is not taken into account as 
regards the occurrence of a schwa. This derivational boundary after a root is associated with the morphological delimitative function of the verbal complex. This is because a native speaker must first recognize where a radical morpheme is in order to understand the functions of prefixes. I will call this phenomenon

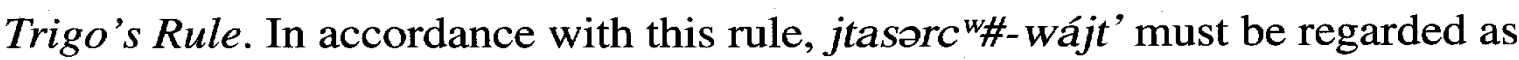
a three-consonant sequence, i.e. $-V T ə R T \#$ - Consider the following examples:

a) $\mathrm{C}_{1}=$ Series I, $\mathrm{C}_{2}=$ Series I, $\mathrm{C}_{3}=$ Series I, $\mathrm{C}_{4}=$ Series I / III: sobš̈\#-wájt' "you kill me", dosš̈\#-róm "I will not kill him/her", doš̌i\#-Xjájt' "I have killed him/ her" (cf. aš̀rá "to kill”, bəššjjt' "I killed you"), dəsk'\#-wájt' "I catch him/her" (cf. dosk'bjt' "I caught him/her").

b) $\mathrm{C}_{1}=$ Series III, $\mathrm{C}_{2}=$ Series I, $\mathrm{C}_{3}=$ Series I, $\mathrm{C}_{4}=$ Series III: jozž\#-wájt' "I dig

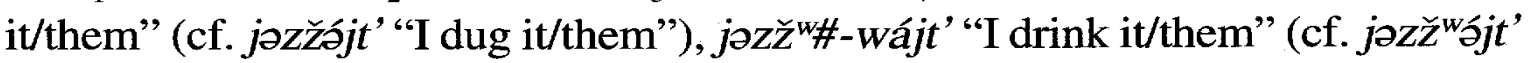
"I drank it/them"), jozz\#-wájt "I roast it/them" (cf. jozzojjt" "I roasted it/them"), jəss\#-wájt' "I weave it /them" (cf. jassájt' "I wove it /them"), jəsx\#-wájt' "I sharpen it/them" (cf. jəsxájt' "I sharpened it /them"), jəš̌ "\#-wájt' "I dye it/ them" (cf. još̌ "'̌jt' "I dyed it/them").

Most of these examples violate the principle of sonority (cf. daš̌̈\#-róm). With the consonant sequence consisting of both personal prefixes and a root in the verbal complex (cf. do-s-ši\#- (him/her-I-kill\#-), Spruit's Rule applies regardless of the kind of sonority. Thus, a schwa appears between $\mathrm{C}_{1}$ and $\mathrm{C}_{2}$. This may be because a type of root having $\mathrm{Ca}$ (cf. do-s-sa\#-wá-jt' (him/her-I-shave\#Dynamic-Finite) "I shave him/her", where both Kuipers' Rule and Spruit's Rule apply) affects the type of root having a single $C$. Therefore, the appearance of a schwa in this case can be formulated as follows: if Trigo's Rule applies, Spruit's Rule must also apply.

\section{$3.4-\mathrm{C}_{1} \mathrm{C}_{2} ə \mathrm{C}_{3} \mathrm{C}_{4} \mathrm{V \# -}$}

Examples where a verbal root has $C V, C C V, C V C, C V C V$, etc. are as follows: a) $\mathrm{C}_{1}=$ Series I, $\mathrm{C}_{2}=$ Series I, $\mathrm{C}_{3}=$ Series II, $\mathrm{C}_{4}=$ Series I: bsambä\#-jt' "I did not see you", bsəmgá\#-jt "I did not take you", dsəmq'ažä\#-jt' "I did not calm him/her", dəbsərdár\#-wajt' "I introduce him/her to you", dsəm̌š̋̈\#-jt' "I did not kill him/her".

b) $\mathrm{C}_{1}=$ Series I, $\mathrm{C}_{2}=$ Series I, $\mathrm{C}_{3}=$ Series I, $\mathrm{C}_{4}=$ Series I: bso3 w3 wa\#-wajt' "I wash you", dsačhwä\#-jt' "I endure him/her".

c) $\mathrm{C}_{1}=$ Series II, $\mathrm{C}_{2}=$ Series I, $\mathrm{C}_{3}=$ Series II, $\mathrm{C}_{4}=$ Series I: jəlsərbá\#-jt' "I 
showed it/them to her".

d) $\mathrm{C}_{1}=$ Series I, $\mathrm{C}_{2}=$ Series II, $\mathrm{C}_{3}=$ Series II, $\mathrm{C}_{4}=$ Series I: dlomk'wabá\#-jt' "she did not wash him/her".

e) $\mathrm{C}_{1}=$ Series I, $\mathrm{C}_{2}=$ Series II, $\mathrm{C}_{3}=$ Series I, $\mathrm{C}_{4}=$ Series I: dəbməčhä\#-n "don't endure him/her!".

Though examples a), b) and c) are explained by the principle of sonority, examples d) and e) violate it. However, none of these examples have schwa before $\mathrm{C}_{4}$, as per Kuipers' Rule. Therefore, Spruit's Rule is also applicable to the threeconsonant sequence $\left(\mathrm{C}_{2} \mathrm{C}_{3} \mathrm{C}_{4}\right)$ : if a schwa does not appear before $\mathrm{C}_{4}$, it will then appear between $\mathrm{C}_{2}$ and $\mathrm{C}_{3}$.

\section{Conclusion}

I conclude that the presence or absence of an unstressed schwa in Abkhaz can be predicted by the following rules:

(1) A schwa cannot appear before $C$ followed by both a and ə. (Kuipers' Rule)

(2) If Kuipers' Rule does not apply in a two-consonant sequence $C C^{\prime}$, and the sonority of $C$ is lower than that of $C^{\prime}$, or the sonority of $C$ is the same as that of $C^{\prime}$, then a schwa can appear between $C$ and $C$ '. In contrast, if the sonority of $C$ is higher than that of $C^{\prime}$, a schwa cannot appear between $C$ and $C$ '. (the principle of sonority)

(3) If Kuipers' Rule does not apply in a three-consonant sequence $C C^{\prime} C^{\prime \prime}$, then a schwa can appear either between $C$ and $C$ ' or between $C$ ' and $C$ "' according to the principle of sonority.

(4) If in a three-consonant sequence - $C C^{\prime} C^{\prime \prime}$ - a schwa does not appear before $C^{\prime \prime}$, then it can appear between $C$ and $C^{\prime}$. (Spruit's Rule)

(5) Presumably, in a construction such as $-R C C^{\prime} V$-, the principle of sonority which operates between $C$ of Series I and $C^{\prime}$ of Series II (or III) may take precedence over Kuipers' Rule. On the other hand, in a construction such as - $T C C^{\prime}$ ' $V$-, the principle of sonority which operates between both $C$ and $C$ ' may be subordinate to Kuipers' Rule. In constructions such as -TRTTV- and -TTTRVKuipers' Rule takes precedence.

(6) If there is a derivational boundary after a root consisting of $C$ or $C C$ in a verbal complex, then $C$ following this root is not taken into account when 
considering the occurrence of a schwa. (Trigo's Rule)

(7) If Trigo's Rule applies in a three-consonant sequence, Spruit's Rule must also apply.

(8) If Kuipers' Rule operates on the last $C$ "' of the four-consonant sequence $C C^{\prime} C$ " $C$ "' $V$, then the principle of sonority is in affect among the first three consonants ( $\left.C C^{\prime} C^{\prime \prime}\right)$. Therefore, a schwa can appear either between $C$ and $C^{\prime}$ or between $C$ ' and $C$ ' in keeping with the principle of sonority.

(9) If Trigo's Rule operates in the four-consonant sequence $-C C$ ' $C$ " $\# C$ "' $V$, then a schwa can appear between $C$ and $C^{\prime}$ according to Spruit's Rule.

(10) In a four-consonant sequence $-C C^{\prime} C{ }^{\prime \prime} C$ '”' $V \#$ - (or $-C C$ ' $C$ "' $C$,' $V C V \#$-) involving a verbal root, a schwa can appear between $C^{\prime}$ and $C$ "' according to Kuipers' Rule and Spruit's Rule.

\section{Afterword}

This article addresses the occurrences of unstressed schwa in Abkhaz, and not issues related to the vowel system. As mentioned in the introduction, there has been heated debate with regard to the vowel systems in the North West Caucasian languages 5 . The following three occurrences of schwa can be identified in Abkhaz: (1) a stressed schwa, (2) an unstressed schwa in a non-word-final position, and (3) an unstressed schwa in a word-final position (cf. sbác"hane "I having scolded you" versus sbácwhan "I scolded you and ..."). In the case of (1), if the element $C$ of the generic symbol " $C(a)$ " is potentially stressed, a stressed schwa appears after the consonant. Some examples cited as "minimal pairs", such as ac'wá "apple" versus ac'wð "little stick" (Chirikba:2003:20), do not represent the phonemic constrast $/ a /$ versus $/ \partial /$, but merely indicate that $C$ before $\partial$ has a potential stress, that is, $a c^{\prime w} \not{\phi}>a c^{\prime w}(\hat{\sigma})>a c^{\prime}{ }^{\prime} \partial$. Therefore, in order to regard a schwa as a phoneme, examples representing the contrast $/ \mathrm{Co} /$ versus $/ C /$ in the unstressed condition are needed. In the case of (2), if my discussion is correct, the contrast $/ C$ / versus $/ C$ / in the unstressed condition does not exist, because the presence or absence of an unstressed schwa is predictable. Therefore, (3), above, will be central to the discussion as to whether or not a schwa can be regarded as a phoneme. To the extent that $I$ have been able to investigate, the contrast $/ C \partial /$ versus $/ C /$ in the unstressed condition is found merely in the examples of those word-final suffixes $-n$ o and $-n$ which mark the positive form of absolutive and the past indefinite respectively, cf. 
minimal pairs, such as sbác wha-nə vs. sbác ${ }^{w h a-n ~(ə ~ a f t e r ~ t h e ~ s u f f i x e s ~} j^{w}, g^{j}, \check{c}^{\prime}$ mentioned in 2.9 is regarded as a free variant). If a verbal root ends in a consonant, ə appears before the suffix - $n$, cf. $s$-á-s-nə (I-it-hit-Absolutive) "I having hit it" vs. $s$-á-sə-n (I-it-hit-Past Indefinite) "I hit it and...". Since ə before $n$ is phonologically irrelevant, these forms can also be considered as minimal pairs, hence /sásnə/ vs. /sásn/. These forms which constitute minimal pairs are merely derived from restricted intransitive verbs, because the forms with word-final stress derived from the other intransitive verbs do not constitute minimal pairs, cf. $d$-ca-nó (he/she-go-Absolutive) "he/she having gone" vs. d-cá-n (he/shego-Past Indefinite) "he/she went and...", and the absolutive form derived from a transitive verb deletes an agent marker, cf. $d$ - $g^{w}$ á-ta-no (him/her-Preverbnotice-Absolutive) "having noticed him/her" vs. $d$-gwá-s-ta-n (him/her-PreverbI-notice-Past Indefinite) "I noticed him/her and ...". Consequently, the functional load of /no/ vs. / $n /$ would appear to be low, but this will have to be investigated in the future, in texts.

\section{Notes}

* I wish to thank my Abkhaz consultant, Mrs. Ana Tsvinaria, who was born in Ochamchira, and is a native speaker of the Abzhywa dialect of Abkhaz. While researching the Abkhaz language in Georgia in the summers of 1997, 2000-2005, she provided me with a lot of information about this language and patiently replied to my many questions. The research upon which this article is based, was supported by a Grant-in-Aid for Scientific Research (C)(2) 2004-2005 (No. 16520236).

Thanks are also due to the three anonymous referees for their useful suggestions as I prepared this article for publication, and to Dr. Mark Weeks for his advice with regard to the English.

1. This Abkhaz consonant system is taken from Chirikba (2003:18). Though according to Chirikba, $j^{w}$ is regarded as a semivowel, this is a voiced pharyngal fricative from the point of view of sonority. Therefore, in this article, $j^{w}$ is treated as a consonant belonging to Series $I$.

2. Also cf. Kuipers (1976:108): "Lomtatidze's statement that Abkhaz schwa is usually stressed reflects the fact that an Abkhaz unit / $p$ / will always have its variant [pə] in stressed position."

3. This word is a verbal complex on which Trigo's Rule operates. For Trigo's Rule see 2.3.

4. Also, some clusters $p s, p \check{s}, p \check{s}^{j}, p \check{s}^{w}$ cannot insert a schwa into their consonants, e.g. apsrá "death, to die", ápssara "to sweep", apst'w̧̧ “animal”, ápsta "valley”, apš̌jará "to take a

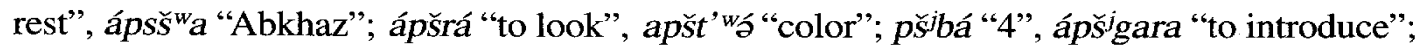
áp̌r"ma "master".

5. For a brief summary of this discussion, see Kuipers (1976:100-103). 


\section{References}

Allen, W. S. 1965. On one-vowel systems, in Lingua 13, no. 2, 111-124.

Chirikba, V. A. 2003. Abkhaz. Languages of the World /Materials 119, Lincom Europa.

Dybo, V. A. 2000. Morfonologizovannye paradigmaticheskie akcentnye sistemy.Tipologija $i$ genezis. Tom. I. Moskva: Jazyki russkoj kul'tury.

Genko, A. N. 1998. Abxazsko-russkij slovar'. Suxum: Alashara.

Hewitt, B. G. 1989. Abkhaz. North Holland. Reprinted by Croom Helm and Routledge.

Kuipers, A. H. 1960. Phoneme and Morpheme in Kabardian. 'S-Gravenhage: Mouton.

1976. Typologically Salient Features of Some North-West Caucasian Languages, in Studia Caucasica, 3, 101-127.

Lomtatidze, K. V. 1967. Abxazskij jazyk, in Jazyki Narodov SSSR IV, 110-122. Moskva: Nauka. Spruit, A. 1985. Stress in Abkhaz, in Studia Caucasica, 6, 31-81.

Trigo, L. 1992. Abkhaz Stress Shift, in G. Hewitt (ed.) Caucasian Perspectives, 191-235. Lincom Europa.

Yanagisawa, T. 2004. Studies in the Structure of the Abkhaz. Verb. Results of a Research Project, Grant-in-Aid for Scientific Research, Nagoya University. 